\title{
POTENSI PASAR PRODUK PERTANIAN ORGANIK DAN BEBERAPA FAKTOR YANG MEMPENGARUHINYA DI KOTA LUWUK
}

\author{
Nurhidayah Layoo*, Winarto Ramlan**, Mustafa Abd. Rahim*** \\ Fakultas Pertanian Universitas Muhammadiyah Luwuk \\ E-mail : nhlayoo@gmail.com
}

\begin{abstract}
ABSTRAK
Tujuan penelitian ini untuk mengetahui : (1) Tanggapan masyarakat Kota Luwuk tentang produk pertanian organik berdasarkan variabel umur, tingkat pendidikan, jenis kelamin, dan jenis pekerjaan; (2) Pengaruh variabel umur dan tingkat pendidikan terhadap kesediaan masyarakat mengkonsumsi atau membeli produk pertanian organik; (3) Ada tidaknya perbedaan kesediaan masyarakat mengkonsumsi atau membeli produk organik berdasarkan perbedaan jenis kelamin dan jenis pekerjaan; (4) Besarnya potensi pasar produk pertanian organik dalam satuan persen. Metode analisis data yang digunakan adalah analisis deskriptif, analisis statistik menggunakan SPSS ver. 16, dan uji Wilcoxon. Hasil penelitian menunjukkan sebagian besar responden memahami bahwa produk organik adalah produk yang sehat, sangat baik dan tidak menggunakan bahan kimia berbahaya, Laki-laki lebih banyak memahami produk organik daripada perempuan, kelompok umur yang paling banyak memahami adalah kelompok 31-42 tahun, responden yang bekerja sebagai dosen dan anggota DPRD paling banyak mengetahui produk organik. Variabel pendidikan menunjukkan yang paling banyak tahu adalah yang berpendidikan S1 dan S2. Berdasarkan analisis statistika, variabel umur tidak berpengaruh signifikan. Sedangkan variabel pendidikan sangat berpengaruh signifikan terhadap kesediaan responden mengkonsumsi/membeli produk organik di Kota Luwuk. Tidak ada perbedaan kesediaan responden mengkonsumsi/membeli produk organik berdasarkan variabel jenis kelamin dan jenis pekerjaan responden. Potensi pasar produk organik di Kota Luwuk sangat besar yakni $88,33 \%$
\end{abstract}

Kata kunci : potensi pasar, produk organik, kesediaan mengkonsumsi

\begin{abstract}
The objectives of research to know : (1) The response of people in Luwuk as to product of organic agriculture based on several variable ; age, education, gender, and occupation. (2) The influence of age and education variable it self towards public awareness to consume or to purchase the organic agriculture product. (3) there is or not different awareness to consume or to purchase the organic agriculture product based on different gender and occupation variable. (4) The numerous potential market of organic agriculture product in percentage. The data analysis methode using descriptive analysis, statistic analysis that using SPSS Ver 16 and Wilcoxon test. It is concluded the research results that the most $(81,67 \%)$ people in Luwuk are aware that the organic product is healthy, good and use unharmfull chemical, in order to be safe to consume and environmentally friendly. According to gender variable there are man most know about the organic product than women. While mostly understand to organic produk, derived from age variable 31-42 years old. In occupation variable indicates that who works as a lecturer and member of DPRD (house of local representatives) most know about organic product. Education sector places the most percentage know the organic product is undergraduate/master degree. Based on statistical analysis, age variable can not influence. In the contrary, education variable is very influence the participant interest to consume/buy the organic product. It's not different in consuming and buying the organic product based on gender moreover occupation kind variable. Potential market of organic product in Luwuk approximately 88,33\%.
\end{abstract}

Keywords : Potential market, Organic product, Awareness of consuming and purchasing 


\section{PENDAHULUAN}

Di kota Luwuk hingga saat ini belum ditemukan adanya tempat khusus penjualan produk pertanian organik, meskipun di pasar tradisional sebenarnya ada produk pertanian organik namun keberadaannya bercampur baur tanpa ada pemisahan yang jelas antara produk organik dengan anorganik sehingga menyulitkan konsumen. Dari sisi produsen, beberapa jenis produk pertanian organik telah diusahakan petani sejak tahun 2007 namun tidak mengalami perkembangan berarti dikarenakan harga jualnya sama saja dengan produk anorganik sementara produksinya persatuan luas areal lebih rendah dibanding produk anorganik sehingga kurang menarik minat petani. Sementara berdasarkan kajian dari kebanyakan ahli bahwa produk organik sangat berpotensi di kota karena terdapat masyarakat kelas menengah atas dengan tingkat pendidikan dan pendapatan yang tinggi. Dengan demikian, sangat kuat dugaan bahwa di Kota Luwuk sebenarnya memiliki potensi cukup besar untuk pemasaran produk organik.

Hasil studi terdahulu menunjukkan bahwa 48\% responden tidak menyukai makanan organik karena masalah tidak peduli lingkungan atau tidak peduli dengan jenis makanan yang dikonsumsi. Konsumen makanan menyehatkan ini berasal dari kalangan atas yang mempunyai pendapatan tinggi maupun yang mempunyai pendapatan rendah, tetapi sebagain besar dari responden mempunyai tingkat pendidikan tinggi (Parkwood Research Associates, 1994 dalam Sutanto, 2002). Potensi pasar yang cukup signifikan untuk produk organik merupakan pendatang baru untuk makanan sehat dan kepedulian lingkungan. Kurang lebih 25\% dari penduduk merupakan kelompok yang cukup potensial mengkonsumsi produk organik (Princeton Survey Research Associates, 1996; Hartman, 1996 dalam Sutanto, 2002) Hasil ini tidak berbeda secara signifikan dari 
keseluruhan penduduk ditinjau dari status sosial ekonomi atau umur, meskipun wanita lebih dominan.

\section{Tujuan Penelitian}

Penelitian ini bertujuan untuk mengetahui : (1) Tanggapan masyarakat Kota Luwuk tentang produk pertanian organik berdasarkan variabel umur, tingkat pendidikan, jenis kelamin, dan jenis pekerjaan; (2) Pengaruh variabel umur dan tingkat pendidikan terhadap kesediaan masyarakat mengkonsumsi atau membeli produk pertanian organik; (3) Ada tidaknya perbedaan kesediaan masyarakat mengkonsumsi atau membeli produk organik berdasarkan perbedaan jenis kelamin dan jenis pekerjaan; (4) Besarnya potensi pasar produk pertanian organik dalam satuan persen.

\section{METODE PENELITIAN}

Lokasi penelitian ini di Kota Luwuk yang merupakan ibukota Kabupaten Banggai. Sedangkan objek penelitian adalah masyarakat yang tinggal menetap di kota Luwuk. Waktu penelitian Agustus-November 2010.

Penelitian ini terdiri atas variabel pengaruh (X) dan variabel terpengaruh (Y). Variabel X yaitu faktor-faktor yang mempengaruhi kesediaan masyarakat mengkonsumsi atau membeli produk pertanian organik, terdiri dari variabel umur (X1) dan Tingkat pendidikan (X2) Sedangkan variabel Y adalah kesediaan masyarakat dalam mengkonsumsi atau membeli produk organik.

Populasi penelitian adalah seluruh masyarakat di Kota Luwuk. Teknik sampling yang digunakan adalah pengambilan sampel kombinasi antara area sampling dan nonproporsional stratified random sampling, secara kronologis sebagai berikut:

1. Area Sampling yaitu mengambil sampel berdasarkan area pekerjaan masyarakat yakni area Universitas (sampel dosen), Rumah sakit dan 
Puskesmas (sampel paramedis), SMA (sampel guru), Pasar (sampel pedagang), Kelurahan Tanjung Tuwis (sampel petani), Kantor DPRD (sampel anggota DPRD), Satuan Kerja Perangkat Daerah (sampel PNS), Bank (sampel karyawan), Kelurahan Luwuk (sampel ibu rumah tangga).

2. nonproporsional Stratified Random Sampling yakni pengambilan sampel secara acak berstrata yang tidak proporsional karena populasi bersifat heterogen sehingga mengambil sampel secara tidak sama dari masing-masing kelompok sampel. Total sampel 180 orang

Teknik pengumpulan data menggunakan quisioner dan wawancara

Teknik Analisa Data :

1. Analisis deskriptif untuk mengetahui potensi pasar, dihitung berdasarkan presentase tanggapan masyarakat yang menjawab bersedia dan sangat bersedia mengkonsumsi/membeli produk organik. Alat analisis ini juga digunakan untuk menguraikan tanggapan masyarakat Kota Luwuk tentang produk pertanian organik berdasarkan variabel umur, jenis kelamin, jenis pekerjaan dan tingkat pendidikan.

2. Analisis regresi linier berganda menggunakan software SPSS ver. 16, untuk mengetahui pengaruh variabel umur, dan tingkat pendidikan terhadap kesediaan masyarakat mengkonsumsi atau membeli produk pertanian organik, dengan menggunakan formula umum menurut Sudjana (1996)

$$
Y=a_{0}+a_{1} X_{1}+a_{2} X_{2}+e
$$

Keterangan :

$\mathrm{Y}=$ Kesediaan masyarakat dalam membeli

$\mathrm{X} 1=$ Umur (tahun)

$\mathrm{X} 2=$ Tingkat pendidikan (tahun)

$\mathrm{a}_{0}=$ Intercept 
$\mathrm{a}_{1}, \mathrm{a}_{2}=$ Koefisien regresi

3. Uji Wilcoxon untuk mengetahui ada tidaknya perbedaan kesediaan membeli atau mengkonsumsi produk organik berdasarkan perbedaan variabel Jenis kelamin dan jenis pekerjaan, karena kedua variabel tersebut memiliki skala pengukuran nominal yakni penggunaan angka 1 dan 2 hanyalah simbol untuk membedakan kategori jenis kelamin laki-laki=1, perempuan=2. dan angka 1-9 untuk kategori jenis-jenis pekerjaan responden.

\section{HASIL DAN PEMBAHASAN}

\section{Deskripsi Tanggapan Responden Terhadap Produk Organik}

Tanggapan responden dalam penelitian ini diawali dengan data pengetahuan responden tentang apa yang dipahami mereka mengenai produk organik. Sebanyak 180 orang responden yang berasal dari berbagai latar belakang umur, jenis kelamin, jenis pekerjaan dan tingkatan pendidikan memberikan jawaban yang beragam tentang hal ini, Jawaban responden terangkum dalam Tabel 1.

Tabel 1. Pemahaman Responden tentang Produk Organik

\begin{tabular}{|c|c|c|c|}
\hline No & Tanggapan Responden & Jumlah Responden (org) & Persentase (\%) \\
\hline 1 & $\begin{array}{l}\text { Produk organik adalah produk yang } \\
\text { sehat }\end{array}$ & 65 & 36,11 \\
\hline 2 & $\begin{array}{l}\text { Produk organik adalah produk yang } \\
\text { sangat baik }\end{array}$ & 31 & 17,22 \\
\hline 3 & $\begin{array}{l}\text { Produk organik adalah produk } \\
\text { alamiah atau tanpa bahan kimia } \\
\text { berbahaya }\end{array}$ & 51 & 28,33 \\
\hline 4 & Tidak tahu & 33 & 18,33 \\
\hline \multicolumn{2}{|r|}{ Jumlah } & 180 & 100,00 \\
\hline
\end{tabular}

Sumber : Data Primer telah diolah, 2010

Sebagian besar responden memahami bahwa produk organik adalah produk yang sehat dan sangat baik bagi manusia karena produk tersebut alamiah sehingga aman dikonsumsi,dan baik bagi lingkungan. Namun terdapat 18,33\% yang tidak tahu produk organik karena belum pernah mendengar informasinya. 
Pemahaman responden mengenai produk organik, ternyata diperoleh dari berbagai sumber informasi seperti yang ditunjukkan padaTabel 2.

Tabel 2. Sumber Informasi yang Diperoleh Responden tentang Produk Organik

\begin{tabular}{|l|l|c|c|}
\hline No & Sumber informasi responden & Jumlah Responden (org) & Persentase (\%) \\
\hline 1 & Media elektronik (Televisi,internet) & 66 & 36,67 \\
2 & Media cetak (Buku,majalah,koran) & 37 & 20,56 \\
3 & Dinas Pertanian (Penyuluh) & 9 & 5,00 \\
4 & Petani & 23 & 12,78 \\
5 & Teman & 12 & 6,67 \\
6 & Belum pernah dapat informasi & 33 & 18,33 \\
\hline \multicolumn{2}{|c|}{ Jumlah } & 180 & 100,00 \\
\hline
\end{tabular}

Sumber : Data Primer telah diolah, 2010

Peran media massa sangatlah besar dalam mensosialisasikan produk organik.

Hal ini dapat dilihat pada Tabel 2, lebih dari separuh responden mengetahui produk organik dari media elektronik dan media cetak. Ironisnya hanya 5\% responden yang menerima informasi produk organik dari sosialisasi petugas pertanian.

Responden yang tidak tahu produk organik ternyata adalah mereka yang belum pernah mendapat informasi tentang produk organik. Persentase responden yang tidak tahu dibandingkan total responden yang diteliti berdasarkan variabel jenis kelamin, umur, jenis pekerjaan dan tingkat pendidikan, ditampilkan secara simultan berikut:

Tabel 3. Persentase Responden yang Tidak Tahu tentang Produk Organik Dibanding Total Responden yang Diteliti Berdasarkan variabel Jenis Kelamin

\begin{tabular}{|c|c|c|c|c|}
\hline No & $\begin{array}{c}\text { Jenis } \\
\text { kelamin }\end{array}$ & $\begin{array}{l}\text { Jumlah Responden yang } \\
\text { menyatakan tidak tahu (org) }\end{array}$ & $\begin{array}{l}\text { Total responden yang } \\
\text { diteliti (org) }\end{array}$ & $\begin{array}{c}\text { Persentase } \\
(\%)\end{array}$ \\
\hline 1 & Laki-Laki & 10 & 71 & 14,08 \\
2 & Perempuan & 23 & 109 & 21,10 \\
\hline \multicolumn{2}{|c|}{ Jumlah } & 33 & 180 & 18,33 \\
\hline
\end{tabular}

Sumber : Data Primer telah diolah, 2010

Berdasarkan variabel jenis kelamin, ternyata laki-laki lebih banyak tahu produk organik daripada perempuan yakni sebanyak 85,92\%, sedangkan perempuan 78,90\%. akan tetapi perbedaan tersebut relative kecil hanya sekitar 7,02\%. 
Tabel 4. Persentase Responden yang Tidak Tahu tentang Produk Organik Dibanding Total Responden yang Diteliti Berdasarkan Variabel Umur

\begin{tabular}{|c|c|c|c|c|}
\hline No & $\begin{array}{c}\text { Umur } \\
\text { (Tahun) }\end{array}$ & $\begin{array}{l}\text { Jumlah Responden yang } \\
\text { menyatakan tidak tahu (org) }\end{array}$ & $\begin{array}{l}\text { Total responden yang } \\
\text { diteliti (org) }\end{array}$ & $\begin{array}{c}\text { Persentase } \\
\text { (\%) }\end{array}$ \\
\hline 1 & $19-30$ & 11 & 54 & 20,37 \\
2 & $31-42$ & 7 & 74 & 9,46 \\
3 & $43-54$ & 14 & 45 & 31,11 \\
4 & $55-66$ & 1 & 7 & 14,29 \\
\hline \multicolumn{2}{r|}{ Jumlah } & 33 & 180 & 18,33 \\
\hline
\end{tabular}

Sumber : Data Primer telah diolah, 2010

Persentase responden tertinggi yang tidak mengetahui produk organik pada

kelompok umur 43-54 tahun. Kelompok usia ini adalah responden yang menyediakan waktu untuk bekerja lebih banyak dibandingkan untuk mengakses informasi.

Sebaliknya persentase terrendah pada kelompok umur 31-42 tahun, yang berarti pula kelompok inilah yang paling banyak mengetahui dan memberi tanggapan yang baik terhadap produk organik, persentasenya mencapai 90,54\%, disebabkan responden dalam kelompok usia ini menyediakan waktu untuk menonton televisi, mengakses internet dan membaca koran atau majalah lebih banyak dibanding kelompok usia lainnya. Pada kelompok usia 31-42 tahun ini pula terdapat responden dengan pekerjaan sebagai dosen,yang secara keseluruhan mengetahui dan memahami produk organik.

Tabel 5. Persentase Jumlah Responden yang Tidak Tahu tentang produk organik dari Total responden yang diteliti Berdasarkan Variabel Jenis Pekerjaan

\begin{tabular}{|c|c|c|c|c|}
\hline No & $\begin{array}{c}\text { Jenis } \\
\text { Pekerjaan }\end{array}$ & $\begin{array}{c}\text { Jmh Responden yang } \\
\text { menyatakan tidak tahu (org) }\end{array}$ & $\begin{array}{c}\text { Total responden } \\
\text { yg diteliti (org) }\end{array}$ & $\begin{array}{c}\text { Persentase } \\
\text { (\%) }\end{array}$ \\
\hline 1 & Dosen & 0 & 23 & 0,00 \\
2 & Paramedis & 3 & 11 & 27,27 \\
3 & Guru & 4 & 14 & 28,57 \\
4 & Wiraswasta & 6 & 41 & 14,63 \\
5 & Petani & 5 & 23 & 21,74 \\
6 & Angg. DPRD & 0 & 4 & 0,00 \\
7 & PNS & 6 & 26 & 23,08 \\
8 & Karyawan & 2 & 22 & 12,50 \\
9 & IRT* & 7 & 180 & 31,82 \\
\hline \multicolumn{2}{|c|}{ Jumlah } & 33 & & 18,33 \\
\hline
\end{tabular}

Sumber : Data Primer telah diolah, 2010

Keterangan IRT* = Ibu Rumah Tangga

Variabel jenis pekerjaan menunjukkan persentase responden tertinggi yang

tidak mengetahui produk organik adalah Ibu Rumah Tangga, sementara untuk yang 
bekerja sebagai dosen dan anggota DPRD semuanya mengetahui kebaikan dan manfaat produk organik, Jika dihubungkan dengan Tabel 6, nampaknya jenis pekerjaan berkaitan dengan tingkat pendidikan misalnya saja pekerjaan sebagai dosen yang kebanyakan berpendidikan S-1, seluruhnya mengetahui produk organik.

Tabel 6. Persentase Jumlah Responden yang Tidak Tahu tentang produk organik dari Total responden yang diteliti Berdasarkan Variabel Tingkat Pendidikan

\begin{tabular}{|c|c|c|c|c|}
\hline No & $\begin{array}{c}\text { Tingkat } \\
\text { Pendidikan }\end{array}$ & $\begin{array}{c}\text { Jumlah Responden yang } \\
\text { menyatakan tidak tahu (org) }\end{array}$ & $\begin{array}{c}\text { Total responden } \\
\text { yg diteliti (org) }\end{array}$ & $\begin{array}{c}\text { Persentase } \\
(\mathbf{\%})\end{array}$ \\
\hline 1 & Tdk tamat SD & 2 & 4 & 50,00 \\
2 & SD & 6 & 16 & 37,50 \\
3 & SMP & 7 & 40 & 17,50 \\
4 & SMA & 9 & 48 & 18,75 \\
5 & Diploma & 5 & 16 & 31,25 \\
6 & S1 & 4 & 43 & 9,30 \\
7 & S2 & 0 & 13 & 0,00 \\
\hline \multicolumn{2}{|r|}{} \\
\hline
\end{tabular}

Sumber : Data Primer telah diolah, 2010

Variabel pendidikan memberikan gambaran bahwa persentase tertinggi yang tidak mengetahui produk organik adalah responden yang tidak tamat SD, Sedangkan yang paling banyak tahu adalah responden yang berpendidikan tinggi (S1 dan S2).

Tabel 7. Tingkat Kesediaan Responden Mengkonsumsi dan Membeli Produk Organik untuk Responden yang Menyatakan Tidak Tahu Produk Organik

\begin{tabular}{|l|l|c|c|c|}
\hline No & $\begin{array}{l}\text { Kesediaan mengkonsumsi } \\
\text { (membeli) }\end{array}$ & $\begin{array}{l}\text { Jml Responden } \\
\text { (org) }\end{array}$ & $\begin{array}{l}\text { TotalResponden } \\
\text { yg diteliti (org) }\end{array}$ & $\begin{array}{l}\text { Persentase } \\
\text { (\%) }\end{array}$ \\
\hline 1 & $\begin{array}{l}\text { Mau sekali mengkonsumsi } \\
\text { (Sangat bersedia membeli) }\end{array}$ & 0 & 79 & 0,00 \\
3 & $\begin{array}{l}\text { Mau mengkonsumsi (Bersedia } \\
\text { membeli) }\end{array}$ & 12 & 18 & 15,00 \\
4 & $\begin{array}{l}\text { Kurang mau mengkonsumsi } \\
\text { (Kurang bersedia membeli) } \\
\text { Tidak mau mengkonsumsi } \\
\text { (Tidak bersedia membeli) } \\
\text { Menolak (sangat tidak } \\
\text { bersedia) }\end{array}$ & 3 & 3 & 100,00 \\
\hline & Jumlah & 0 & 0 & 100,00 \\
\hline
\end{tabular}

Sumber : Data Primer telah diolah, 2010

Seluruh responden yang menyatakan kurang mau mengkonsumsi produk organik adalah responden yang tidak mengetahui produk organilk. Ada pula responden yang tidak bersedia mengkonsumsi atau membeli produk organik karena pemahaman yang keliru tentang produk organik. 
Lebih lanjut menurut responden, lokasi atau tempat penjualan produk organik sebaiknya (1) di pasar karena mudah dijangkau, sebagian besar responden yakni 67,78\% memilih alternatif lokasi ini. (2) di lokasi budidaya produk organik (kebun) agar lebih meyakinkan keorganikannya (21,11\%), dan (3) di swalayan karena lebih bersih sehingga produk organik tetap tidak terkontaminasi selain lebih nyaman untuk berbelanja $(11,11 \%)$.

\section{Analisis Statistik Pengaruh Variabel Umur (X1) dan Pendidikan (X2) terhadap Kesediaan Mengkonsumsi/Membeli Produk Organik (Y)}

Tabel 8. Ringkasan Nilai Koefisien Regresi, Uji t, dan Signifikansi

\begin{tabular}{|l|c|c|c|}
\hline Variabel & Koef Regresi & Uji t & Signifikansi \\
\hline Konstanta $\left(\mathrm{a}_{0}\right)$ & 3,283 & & \\
Umur (X1) & 0,004 & 0,730 & 0,466 \\
Pendidikan $(\mathrm{X} 2$ & 0,070 & 4,987 & 0,000 \\
\hline
\end{tabular}

Sumber : Hasil Analisis SPSS ver. 16

Berdasarkan nilai-nilai pada Tabel 8, dapat dituliskan persamaan regresi dari pengaruh Umur dan Tingkat Pendidikan terhadap kesediaan responden mengkonsumsi/membeli produk organik di Kota Luwuk,sebagai berikut.

$$
\mathrm{Y}=3,283+\mathbf{0 , 0 0 4 X 1}+\mathbf{0 , 0 7 0 X 2}+\mathrm{e}
$$

Nilai Konstanta $\left(\mathrm{a}_{0}\right)$ 3,283 artinya apabila variabel umur dan tingkat pendidikan konstan, maka kesediaan responden mengkonsumsi/membeli produk organik tetap akan meningkat sebesar 3,283 satuan. Nilai koefisien regresi $a_{1}$ 0,004 artinya apabila umur responden bertambah sebesar satu satuan (1 tahun) maka kesediaan mengkonsumsi/membeli mereka akan meningkat sebesar 0,004 satuan. Nilai koefisien regresi $a_{2}$ 0,070 artinya apabila pendidikan responden bertambah sebesar satu satuan (1 tahun) maka kesediaan mengkonsumsi /membeli mereka akan meningkat sebesar 0,070 satuan 
Uji t untuk mengetahui apakah menerima atau menolak hipótesis bahwa variabel umur mempengaruhi kesediaan reponden dalam mengkonsumsi/membeli produk organik pada taraf kepercayaan $95 \%(\alpha 0,05)$, ternyata diperoleh nilai $t_{\text {hitung }} 0,730$ $<t_{\text {tabel }}$ 1,645 . Nilai ini menunjukkan bahwa hipótesis ditolak, jadi berdasarkan hasil penelitian ini variabel umur tidak mempengaruhi kesediaan responden mengkonsumsi/membeli produk organik. Hal ini juga ditunjukkan oleh nilai signifikansi variabel umur sebesar 0,466 $>\alpha$ 0,05 yang berarti pengaruh umur tidak signifikan.

Sedangkan hipótesis yang menyatakan bahwa variabel pendidikan mempengaruhi kesediaan reponden dalam mengkonsumsi/membeli produk organik pada taraf kepercayaan 95\% ( $\alpha$ 0,05), ternyata diperoleh nilai $t_{\text {hitung }} 4,987>t_{\text {tabel }} 1,645$. Nilai ini menunjukkan bahwa hipótesis diterima, jadi variabel pendidikan memang mempengaruhi kesediaan responden mengkonsumsi /membeli produk organik. Hal ini juga ditunjukkan oleh nilai signifikansi variabel pendidikan sebesar $0,000<\alpha 0,05$ yang berarti pengaruh pendidikan sangat signifikan.

Tabel 9. Ringkasan Nilai Koefisien Korelasi Berganda, Koefisien Determinasi Berganda dan Uji F

\begin{tabular}{|l|r|}
\hline Uraian & Nilai \\
\hline Koefisien Korelasi berganda $(\mathrm{R})$ & 0,355 \\
Koefisien Determinasi berganda $\left(\mathrm{R}^{2}\right)$ & 0,116 \\
Uji F & 12,757 \\
\hline
\end{tabular}

Sumber : Hasil Analisis SPSS ver. 16

Hasil uji F menunjukkan nilai $F_{\text {hitung }} 12,757>F_{\text {tabel }}$ 3,04, artinya secara serentak variabel umur (X1) dan pendidikan (X2) mempengaruhi kesediaan responden mengkonsumsi/membeli produk organik pada taraf kepercayaan 95\% $(\alpha 0,05)$.

Koefisien korelasi ganda 0,355 artinya keeratan hubungan antara variabelvariabel x dengan variabel Y sebesar 35,5\%, menunjukkan adanya hubungan yang langsung atau positif antara variabel umur dan pendidikan terhadap kesediaan 
responden mengkonsumsi/membeli produk organik, meskipun hubungannya agak lemah. Hal ini dipertegas pula oleh nilai koefisien determinasi ganda 0,116 yang berarti perubahan atau naik turunnya nilai kesediaan responden mengkonsumsi/membeli produk organik di Kota Luwuk ditentukan oleh umur dan pendidikan responden hanya sebesar $11,6 \%$, sisanya sebesar $88,4 \%$ ditentukan oleh variabel lain yang tidak diteliti.

Variabel-variabel yang tidak diteliti tersebut antara lain ketersediaan produk organik di pasar, harga yang terjangkau, dan pemahaman yang lebih baik tentang manfaat produk organik melalui intensitas sosialisasi. Kemungkinan variabel-variabel ini lebih berpengaruh jika dimasukkan ke dalam model. Akan tetapi tidak diteliti karena keterbatasan-keterbatasan yang ada seperti waktu, tenaga dan biaya penelitian.

\section{Uji Wilcoxon Pengaruh Variabel Jenis Kelamin (X3) dan Jenis Pekerjaan (X4) terhadap Kesediaan Mengkonsumsi/Membeli Produk Organik (Y)}

Berdasarkan uji Wilcoxon menunjukkan bahwa kesediaan responden mengkonsumsi/membeli produk organik antara responden laki-laki (1) dan perempuan (2) tidak ada perbedaan. Demikian pula kesediaan responden mengkonsumsi/membeli produk organik antara responden yang bekerja sebagai dosen (1), paramedis (2), Guru (3) dan seterusnya tidak berbeda secara signifikan.

Uraian di atas ditunjukkan oleh nilai asymp Sig 0,000< $\alpha .0,05$ untuk pengaruh jenis kelamin terhadap kesediaan responden mengkonsumsi/membeli produk organik. Dan nilai asymp Sig. $0.001<0,05$ untuk pengaruh jenis pekerjaan terhadap kesediaan responden mengkonsumsi/membeli produk organik di Kota Luwuk.

\section{Potensi Pasar Produk Organik}

Potensi pasar produk organik dalam penelitian ini dilihat dari besarnya Kesediaan responden mengkonsumsi dan kemungkinan membeli produk organik, 
dihitung dari persentase jumlah responden yang memberikan jawaban bersedia dan sangat bersedia mengkonsumsi dan membeli produk organik, Ternyata ditemukan potensi pasar produk organik yang sangat besar yakni 88,33\%, Potensi ini perlu ditindaklanjuti dengan peningkatan produksi yang seiring dengan pemasyarakatannya demi mensukseskan program “Go Organik 2010”. Data lebih rinci disajikan pada Tabel 10.

Tabel 10. Tingkat Kesediaan Responden Mengkonsumsi dan Membeli Produk Organik

\begin{tabular}{|l|l|c|c|}
\hline No & Kesediaan mengkonsumsi (membeli) & $\begin{array}{l}\text { Jumlah Responden } \\
\text { (org) }\end{array}$ & Persentase (\%) \\
\hline 1 & $\begin{array}{l}\text { Mau sekali mengkonsumsi (Sangat } \\
\text { bersedia membeli) } \\
\text { Mau mengkonsumsi (Bersedia }\end{array}$ & 79 & 43,89 \\
3 & $\begin{array}{l}\text { membeli) } \\
\text { Kurang mau mengkonsumsi (Kurang } \\
\text { bersedia membeli) }\end{array}$ & 18 & 14,44 \\
4 & $\begin{array}{l}\text { Tidak mau mengkonsumsi (Tidak } \\
\text { bersedia membeli) } \\
\text { Menolak (sangat tidak bersedia) }\end{array}$ & 3 & 1,67 \\
\hline$\quad$ Jumlah & 0 & 0,00 \\
\hline
\end{tabular}

Sumber : Data Primer telah diolah, 2010

Berdasarkan Tabel 10, maka jumlah responden yang menjawab bersedia dan sangat bersedia mengkonsumsi/membeli produk organik sebanyak 159 orang atau 88,33\%. Dengan mengacu pada data ini maka dapat dikatakan bahwa potensi pasar produk organik di Kota Luwuk sebesar 88,33\%. Sisanya sebesar 11,67\% menyatakan kurang dan tidak bersedia membeli produk organik. Kelompok ini adalah responden yang belum pernah dengar dan belum tahu produk organik.

\section{KESIMPULAN DAN SARAN}

\section{Kesimpulan}

Berdasarkan hasil penelitian, disimpulkan bahwa :

1. Sebagian besar $(81,67 \%)$ responden memahami bahwa produk organik adalah produk yang sehat, sangat baik dan tidak menggunakan bahan kimia berbahaya (alamiah), sehingga aman untuk dikonsumsi, dan baik bagi lingkungan. Berdasarkan 
variabel jenis kelamin, laki-laki lebih banyak memahami produk organik daripada perempuan. Berdasarkan variabel umur, kelompok umur 31-42 tahun, yang paling banyak memahami produk organik. Berdasarkan variabel jenis pekerjaan menunjukkan persentase responden tertinggi yang tidak mengetahui produk organik adalah Ibu Rumah Tangga, sementara yang paling banyak memahami adalah dosen dan anggota DPRD.. Sedangkan variabel pendidikan menunjukkan bahwa persentase tertinggi yang tidak mengetahui produk organik adalah responden yang tidak tamat SD, dan yang paling banyak memahami ádalah responden berpendidikan S1 dan S2.

2. Variabel umur tidak berpengaruh signifikan, sedangkan Variabel pendidikan sangat berpengaruh signifikan terhadap kesediaan responden mengkonsumsi/membeli produk organik di Kota Luwuk.

3. Tidak ada perbedaan kesediaan responden mengkonsumsi/membeli produk organik berdasarkan variabel jenis kelamin dan jenis pekerjaan responden.

4. Potensi pasar produk organik di Kota Luwuk sangat besar yakni 88,33\%

\section{Implikasi Kebijakan}

1. Perlu pemasyarakatan produk organik melalui peningkatan Intensitas sosialisasi produk organik ke konsumen dan produsen, untuk mendongkrak pemahaman masyarakat terhadap pentingnya produk organik, terutama bagi masyarakat dengan tingkat pendidikan SLTA ke bawah.

2. Oleh karena potensi pasar produk organik sangat besar, maka perlu peningkatan produksi dan ketersediaan produk organik di pasar dengan melakukan pemisahan secara fisik dan penetapan harga yang berbeda antar produk organik dan anorganik untuk mempertegas keberadaan produk organik 


\section{UCAPAN TERIMA KASIH}

Ucapan terima kasih kepada Bapak Moh. Gifari Sono, ST.,MM sebagai Ketua Litbang Unismuh Luwuk, seluruh responden penelitian, Saudara Sahbuddin Lataha dan Meldi Batili, Ibu Helen Setia Aprilia, Ibu Diah Eka Yanti, dan bapak Marlan, temanteman di Fakultas Pertanian. Serta semua pihak yang telah berkontribusi dalam penelitian ini, sekecil apapun kami sangat menghargainya.

\section{DAFTAR PUSTAKA}

Bambang Widjanarko Otok, 2009. Uji Wilcoxon, Materi Pelatihan Analisis data

Statistika Untuk Penelitian. Kerjasama Universitas Airlangga dan Universitas Muhammadiyah Luwuk

Departemen Pertanian, 2002. SNI 01-6729-2002, tentang Sistem Pangan Organik

Karwan A. Salikin, 2003. Sistem Pertanian Berkelanjutan. Kanisius, Yogyakarta

Rahman Sutanto, 2002. Pertanian Organik, Menuju Pertanian Alternatif dan Berkelanjutan, Kanisius, Yogyakarta

\section{Pengembangannya, Kanisius, Yogyakarta}

Sinar Tani Oline, 2008. Program Go Organik 2010, Gerakan Mempercepat Pertanian Organik

Sudjana, 1996. Metoda Statistika, Tarsito, Bandung 